\title{
(2) \\ Bamboo Trade and Future Prospects in the Central Himalaya: A case study of the traditional artisans of Uttarakhand, India
}

\author{
Manju Sundriyal and Rakesh Chandra Sundriyal
}

\section{Research}

\begin{abstract}
In India bamboo is valuable in the rural livelihoods. However, despite improvement efforts the conditions of bamboo resources and traditional artisans have been deteriorating over the years. To improvise the socio-economic status of the artisans, different state governments are looking for information on the resource as well as artisans' skills so that necessary amendments could be accomplished in government policies and programs to develop this sector as an important vehicle for rural development. This article is based on an investigation that was conducted in Uttarakhand state, India using questionnaires. We report on bamboo species being used, indigenous knowledge of articles made from bamboo, resource utilization patterns, and management status of bamboo in Uttarakhand state. The paper also discusses major bottlenecks of the trade along with the potential interventions that could be used to enhance bamboo-based livelihoods in the region.
\end{abstract}

\section{Introduction}

For centuries bamboo has been a central part of many rural societies in Asia, Africa and Latin America (Frith 2008). It has provided communities with wide range of opportunities, i.e., housing, utensils, food and agricultural products, thus plays an important role in the socio-economic status of people (Buckingham 2010, Lobovikov et al. 2007). It is important to learn that information on traditional uses of bamboos varies between and within regions (Buckingham 2009, Lobovikov et al. 2007, Ram \& Tandon 1997). However, until recently the bamboo-artisans have maintained poor status as their material and products are considered cheap and low-quality items. There is a need to develop new livelihood opportunities through bamboo by improving the quality of products and targeting high value markets (Ghimire 2008, Nath \& Das 2008). For this purpose it is important to learn the concerns of bamboo-artisans' in different regions so that appropriate actions may be taken for development of bamboo-trade in diverse areas.

Bamboo are fast growing plants that can be harvested annually without deteriorating the supply-base, which makes bamboo an exceptional resource from economic and environmental perspectives (Buckingham 2009). India has a maximum area of 8.96 million hectares under bamboo in the world (Anonymous 2005b). It is the second richest country in terms of bamboo genetic diversity after China with a total of 136 species in 75 genera (Biswas 2004, Rai $\&$ Chaudhary1998). Despite having such a rich resource base and widespread living traditions of bamboo use, the tremendous potential of bamboo lies dormant and largely untapped in comparison with countries like China, Japan and Taiwan whose names are synonymous with bamboo in the world (Sastry 2001). In recent times, though bamboo is largely used for industrial development thus offering newer opportunities to the world. On the other hand the traditional uses of bamboo are gradually disappearing in view of fast economic growth of different countries (Frith 2008, Ghimire 2008, Nath \& Das 2008). Much effort

\section{Correspondence}

Manju Sundriyal, Rakesh Chandra Sundriyal, Govind Ballabh Pant Institute of Himalayan Environment \& Development, KosiKatarmal, Almora-263643, Uttarakhand, INDIA.

Herbal Research \& Development Institute, Mandal, Gopeshwar District- Chamoli, Uttarakhand, INDIA.

manjusundriyal@yahoo.co.in

Ethnobotany Research \& Applications 9:445-454 (2011)

Published: December 20, 2011 
and planning are desired to obtain a balance of industrial and traditional uses of bamboo. The industrial development should not overtake the traditional bamboo-artisan as they are intimately associated with bamboo since ancient times.

The total number of bamboo basket weavers in India was estimated at 0.82 million in 1981 of which 0.69 million lived in rural areas and this number has increased over the years (Saxena 2004). These communities have the expertise and skills for processing bamboo and make diverse items from it. However they are not able to receive sufficient compensation for their labor (Sundriyal et al. 2002). The available literature on traditional use of bamboo lacks reliable quantitative data which otherwise could make a useful compendium of information that may provide clues for development of its trade among bamboo-artisans (Kumar 2009, Sastry 2001). An acquaintance with the ground realities of bamboo-artisans and the resource they use, therefore, is highly desirable to assess the status and vulnerability of the trade in order to augment the quality of this important rural enterprise (Anonymous 2006). In this study an attempt has been made to assess the indigenous knowledge on bamboo resource utilization patterns, management, and constraints of the traditional bamboo entrepreneurs with a goal to identifying the developmental bottlenecks and possibilities of upgrading bamboo based livelihoods for rural folks of Uttarakhand state. It is expected that such information could help to improve the status of bamboo-artisans, their trade and resources.

\section{Study area}

Uttarakhand is located between $28^{\circ} 43^{\prime} \mathrm{N}$ to $31^{\circ} 27^{\prime} \mathrm{N}$ longitude and $77^{\circ} 34^{\prime} \mathrm{E}$ to $81^{\circ} 02^{\prime} \mathrm{E}$ latitude. It was formed in 2000 as the $27^{\text {th }}$ state of India and has a total area of $53,483 \mathrm{~km}^{2}$. The entire state forms part of the Central Himalaya and has three distinct physiographic regions, the Himalaya, the Siwalik and the plains in an elevation gradient ranging from 300 to $3500 \mathrm{~m}$. It is endowed with diverse vegetation types, which range from tropical deciduous to alpine forests, grasslands, high altitude glaciers and a vast stretch of rivers, rivulets and wetlands.

The Uttarakhand state has a population of about 8.5 million people with average density of 159 per square $\mathrm{km}$ and a decadal growth rate of $19.2 \%$ during 1991-2001, which was lower than the national average. The total number of inhabited villages is 15,761 including forest villages. One of the promising demographic features of the state is its high literacy rate $(71.6 \%)$, especially among females $(60 \%)$. Administratively the state is divided into 13 districts. It is estimated that $65 \%$ of the total land area of the state is under forest, of which $43 \%$ is dense forest. Nearly $24,637 \mathrm{~km}^{2}$ area is under reserved forest, $9883 \mathrm{~km}^{2}$ is under protected forests and $131 \mathrm{~km}^{2}$ is under private forest (Anonymous 2005a). The bamboo forests are dominated in lower elevations particularly in Siwalik Hills, though the species occur intermittently at various elevations throughout the state.

Agriculture is the mainstay of the people of Uttarakhand with over $75 \%$ of the population dependent on it. However, landholdings are small (50\% of all landholdings are less than 0.5 ha in size, and $70 \%$ under 1 ha). The net sown area is only about $14 \%$ of the total reported area. The cropping intensity is about $160 \%$. The economy in rural areas is subsistence in nature with high dependence on natural resources. A few communities are totally dependent on natural resources for their sustenance, viz. bamboo-artisans. There is a rich tradition of using bamboo and ringal for household purposes. The state has over 460 villages that depend on these resources as their major livelihood per the records of the Bamboo \& Fibre Development Board (Anonymous 2005a). Bamboo is used for various purposes in all 13 districts of Uttarakhand with $1394 \mathrm{~km}^{2}$ area growing it. The gross commercial bamboo standing stock is estimated at $45,000 \mathrm{~m}^{3}$ in the state (Anonymous 2005a). There are two broad groups of bamboo, thickbamboo and thin reed like bamboo (ringal).

\section{Methods}

This study was planned to assess resource utilization patterns and the socio-economic status of bamboo-artisans in the state of Uttarakhand. The methods employed in this investigation were designed in order to provide baseline information on the use of bamboo in the local system. Such information and data were gathered through field surveys and strategic investigations of bamboo-artisans. The area under bamboo in the state was obtained from the records of the Forest Department (Anonymous 2005c), while number of artisans' villages in the state was gathered from the records of Uttarakhand Bamboo \& Fibre Development Board (Anonymous 2005a), district administrations and ground verification. Four districts, viz. Almora, Nainital, Bageshwar and Uttarkashi were identified and selected with the help of experts and the UBFDB, Government of Uttarakhand. A total of 20 artisans' villages from these four districts, comprising 132 bamboo- and 560 ringal-artisan families were surveyed. Documentation of the community indigenous knowledge system (IKS) of bamboo artifacts was done through social surveys. A questionnaire was designed to gather data. The questionnaire was administered through formal and informal interviews with the artisans to obtain detailed information with reference to species used, areas and mode of collection, time spent for collection of the raw material, and general condition (poor, good, better) of the resource at site (Sarkar \& Sundriyal 2002, Sundriyal et al. 2002). An inventory of different bamboo products, their local names, and their uses was also noted. The quantity of raw material used for making different products, designs used, time taken for making these items, and mode of selling of the product was also investigated (Sundriyal et al. 2002). Marketing of the items was assessed through visiting vil- 
lages, festivals and small towns. A cost-benefit analysis was done by assessing all cost involved in raw material purchase; labor used in collection of raw material, processing and product making; and net sale prices for different items. The socio-economic status of the artisans was assessed by gathering information on the net income from selling bamboo products, monthly expenditure of an average household, and net savings if any. Discussions were also held with the artisans to get their perception and views about possible ways and means for bamboo resource management and conservation, the demand and supply status of the resource, and the community need for the products (Singh et al. 2003, Upreti \& Sundriyal 2001). All the data and information were crosschecked at various levels and analyzed statistically. To assess trade related problems being faced by the communities and future strategies for bamboo sector development, the artisans were asked to provide three most pressing issues/ priorities that they feel important for improving their socio-economic status based on their experience and perception with the bamboo trade (Sarkar and Sundriyal 2002). Sub-

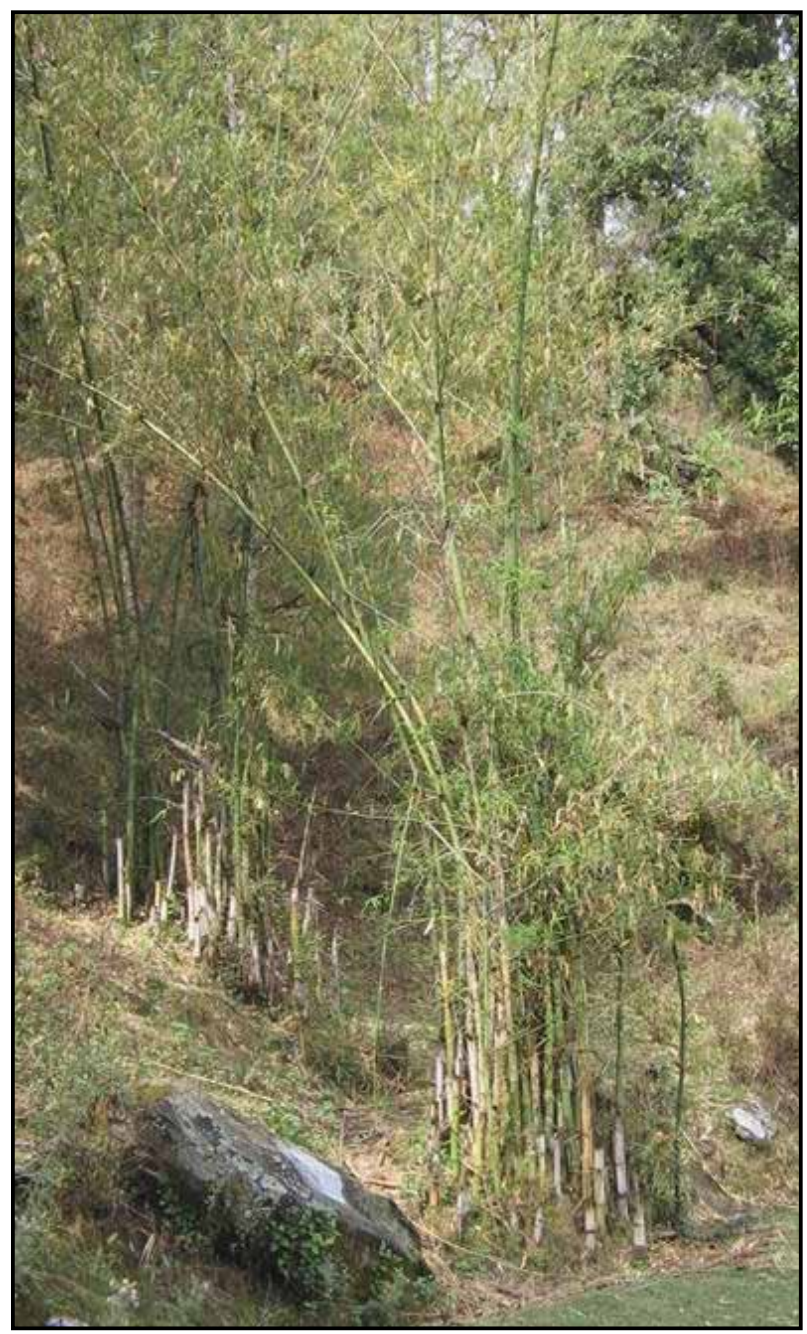

Figure 1. Bamboo plant, Uttarakhand, India. sequently they were also invited to rank the issues as I, II or III based on their perception. Rank I, II and III represent very high, high and medium priority for any given preference by the community on bamboo and its trade. All of the priorities were categorized and arranged in tabular form. All species used by the communities were collected and made into herbarium voucher specimens. These were identified with the help of plant experts and available flora with the Botanical Survey of India, and Forest Research Institute herbarium, Dehradun (BSD).

\section{Results}

\section{Bamboo stalks and species}

Bamboo in the state is categorized into two groups; bamboo and ringal bamboo. Bamboo is a thick, long and slender like plant (Figure 1) while ringal is thin spineless plant (Figure 2). In Uttarakhand state, eight bamboo species belonging to five genera were recorded that grow natural-

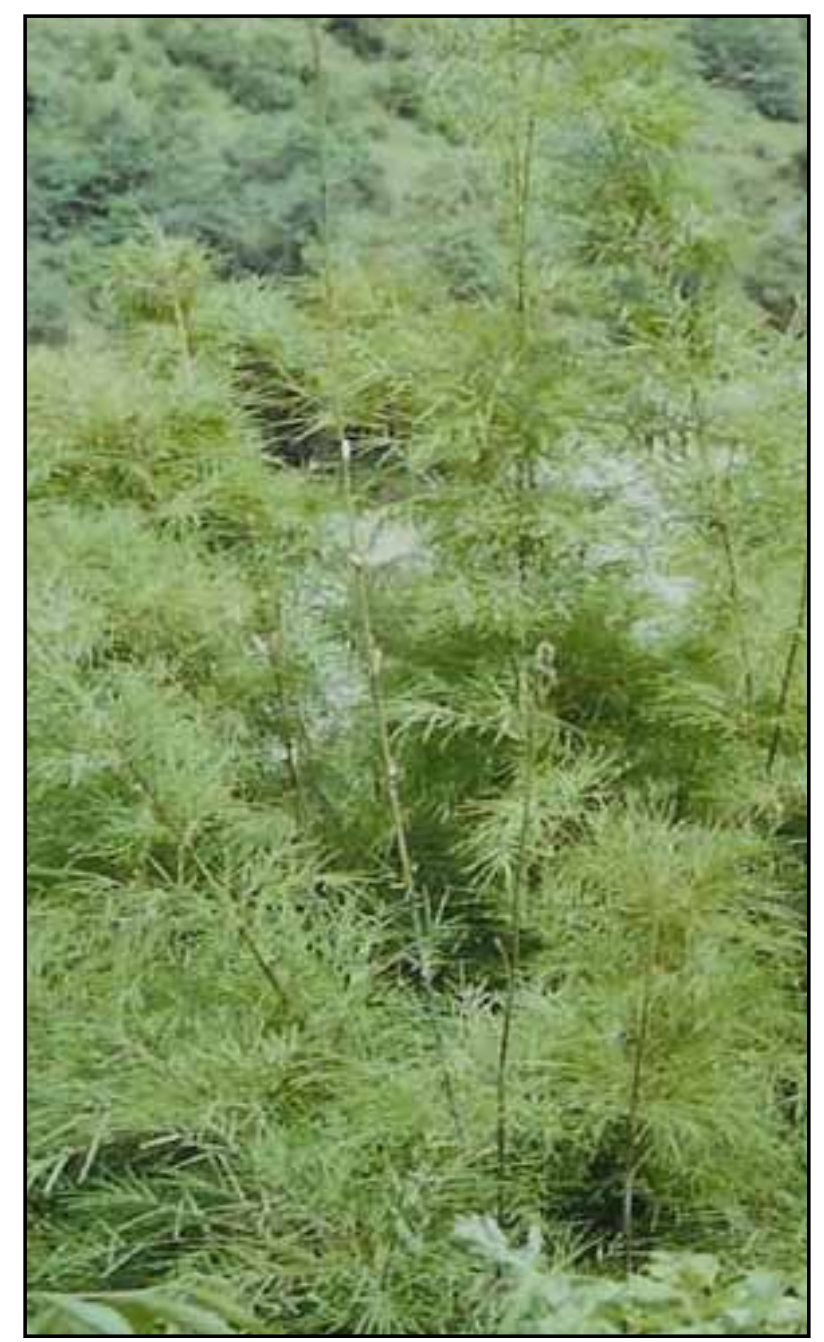

Figure 2. Ringal-bamboo plant, Uttarakhand, India. 
ly: Dendrocalamus strictus (Roxb.) Nees, Dendrocalamus somdevae H.B. Naithani, Dendrocalamus patellaris Gamble, Bambusa bambos (L.) Voss (all bamboo species), and Drepanostachyum falcatum (Nees) Keng f., Himalayacalamus falconeri (Munro) Keng f. , Thamnocalamus spathiflorus (Trin.) Munro, and Sinarundinaria anceps (Mitford) C.S. Chao \& Renvoize (all ringal species). Ringal species grow at mid and high hill areas of the state (> 2000 $\mathrm{m}$ ) while bamboo is generally found at mid and low hills $(<2000 \mathrm{~m})$. There are a large number of other species that have been planted in bamboosetums (a bamboo garden with different bamboo species) and other areas. Dendrocalamus strictus grows in low elevations that earn maximum revenue for the Forest Department (Table 1). Dendrocalamus somdevae dominates mid-hills and the species is similar to Dendrocalamus hamiltonii Nees \& Arn. ex Munro except for the wall thickness, thus often misquoted as later species. The other two bamboo species ( $D$. patellaris, $B$. bambos) exhibit restricted distribution. Among ringal species, dev-ringal $(H$. falconeri) is the most commonly used species for making different articles. Himalayacalamus falconeri is recorded at highest elevations among all the bamboo species. Drepanostachyum falcatum and Sinarundinaria anceps are other two species used in the local system for different articles. The communities that make articles from bamboo and ringal are called Baruree and Rudia, respectively.

Of the 13 total districts in Uttarakhand, Uttarkashi district has the maximum area under bamboo production followed by Rudraprayag, Haridwar and Nainital districts (Figure 3). Bageshwar, Chamoli, Pithoragarh, Tehri and Uttarkashi districts have ringal species only, while Udham Singh Nagar, Haridwar and Champawat districts are com-

Table 1. Major bamboo and ringal species growing naturally in Uttarakhand state, India.

\begin{tabular}{|c|c|c|c|c|}
\hline Species & $\begin{array}{l}\text { Local } \\
\text { name }\end{array}$ & $\begin{array}{l}\text { Distribution } \\
\text { (meters above } \\
\text { sea level) }\end{array}$ & Habitat & Uses \\
\hline \multicolumn{5}{|l|}{ Bamboo: } \\
\hline $\begin{array}{l}\text { Dendrocalamus strictus } \\
\text { (Roxb.) Nees }\end{array}$ & $\begin{array}{l}\text { Lathi } \\
\text { bans }\end{array}$ & $325-1000$ & $\begin{array}{l}\text { Low-hill moist forests } \\
\text { (Siwalik)- Lansdowne } \\
\text { forest Division }\end{array}$ & $\begin{array}{l}\text { For making bamboo } \\
\text { articles and extensively } \\
\text { raw material is used } \\
\text { in paper industry }\end{array}$ \\
\hline Bambusa bambos (L.) Voss & $\begin{array}{l}\text { Choya } \\
\text { bans }\end{array}$ & $500-1000$ & Sub-Himalayan tracts & For household articles \\
\hline $\begin{array}{l}\text { Dendrocalamus somdevae } \\
\text { H.B. Naithani }\end{array}$ & $\begin{array}{l}\text { Khokhal } \\
\text { bans }\end{array}$ & $600-1500$ & $\begin{array}{l}\text { Mid-hills, homesteads } \\
\text { and on common land. }\end{array}$ & $\begin{array}{l}\text { For making baskets and } \\
\text { other house hold articles }\end{array}$ \\
\hline $\begin{array}{l}\text { Dendrocalamus patellaris } \\
\text { Gamble }\end{array}$ & & $1200-1500$ & $\begin{array}{l}\text { In Kumaon region } \\
\text { in mid hills }\end{array}$ & For basketry work \\
\hline \multicolumn{5}{|l|}{ Ringal-bamboo: } \\
\hline $\begin{array}{l}\text { Drepanostachyum falcatum } \\
\text { (Nees) Keng f. }\end{array}$ & $\begin{array}{l}\text { Ghad } \\
\text { ringal }\end{array}$ & $1500-2100$ & $\begin{array}{l}\text { Found as dense or } \\
\text { moderately dense } \\
\text { undergrowth in } \\
\text { evergreen forests of oak, } \\
\text { deodar, chir and } \\
\text { rhododendron species }\end{array}$ & $\begin{array}{l}\text { For making baskets, } \\
\text { fishing rods, mats } \\
\text { and animal fodder } \\
\text { in lean period }\end{array}$ \\
\hline $\begin{array}{l}\text { Sinarundinaria anceps (Mitford) } \\
\text { C.S. Chao \& Renvoize } \\
\text { (syn. Chimonobambusa } \\
\text { jaunsarensis (Gamble) } \\
\text { Bahadur \& Naithani) }\end{array}$ & $\begin{array}{l}\text { Jumra } \\
\text { ringal }\end{array}$ & $2100-2700$ & $\begin{array}{l}\text { Grow naturally in clusters } \\
\text { inside the forest }\end{array}$ & $\begin{array}{l}\text { For a few agricultural } \\
\text { implements }\end{array}$ \\
\hline $\begin{array}{l}\text { Himalayacalamus falconeri } \\
\text { (Munro) Keng f. } \\
\text { (syn. Thamnocalamus } \\
\text { falconeri Munro) }\end{array}$ & $\begin{array}{l}\text { Dev } \\
\text { ringal }\end{array}$ & $1900-2750$ & $\begin{array}{l}\text { Grow naturally on } \\
\text { the hills and/or } \\
\text { under oak forests }\end{array}$ & $\begin{array}{l}\text { For making fans, } \\
\text { umbrellas, crowns, } \\
\text { baskets, trays for } \\
\text { offerings to gods, and } \\
\text { other household items }\end{array}$ \\
\hline $\begin{array}{l}\text { Thamnocalamus spathiflorus } \\
\text { (Trin.) Munro (syn. } \\
\text { Thamnocalamus aristatus } \\
\text { (Gamble) E.G. Camus) }\end{array}$ & $\begin{array}{l}\text { Thaam } \\
\text { ringal }\end{array}$ & $2500-3500$ & $\begin{array}{l}\text { On moist and shady } \\
\text { slopes within and } \\
\text { outside forest areas }\end{array}$ & $\begin{array}{l}\text { Agricultural implements } \\
\text { and pipes for Hookahs }\end{array}$ \\
\hline
\end{tabular}




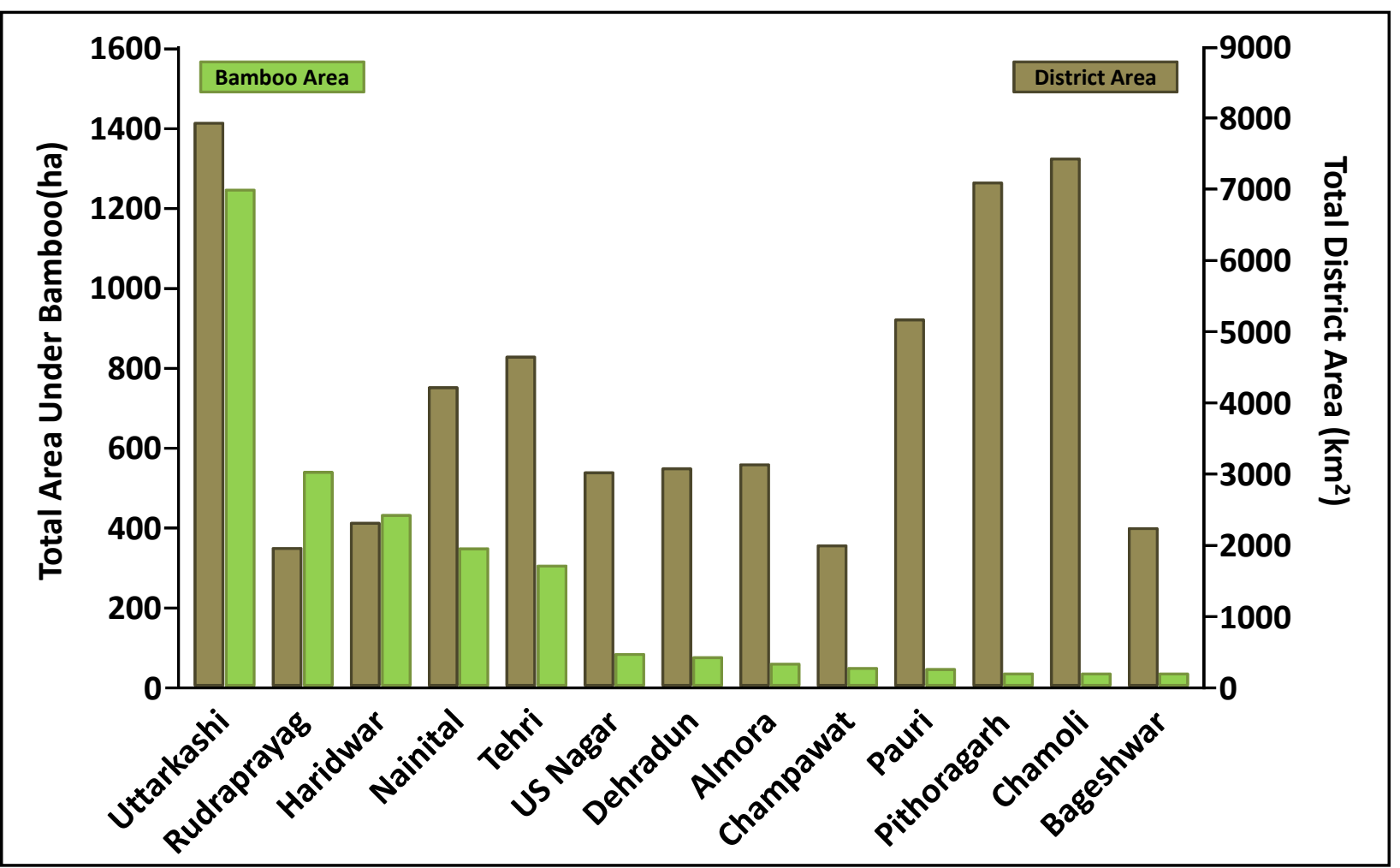

Figure 3. Total net area under bamboo production and district area for each district in Uttarakand state, India.

prised of bamboo species only. All other districts are comprised of both bamboo and ringal species.

\section{Traditional bamboo and ringal products}

The state has as many as 451 bamboo artisan villages and their distribution varies in different districts (Figure 4). Bageshwar district has the highest number of bamboo-artisan villages. An analysis of 20 villages spreading in four districts of the state (viz. Almora, Bageshwar, Uttarkashi and Nainital) revealed that the artisans make 62 bamboo and ringal items, which comprised a va- riety of baskets, mats, toys and instruments, and various other utility items, which exhibits a diverse knowledge base (Figure 5). However, only 14 items were recorded to be sold in the villages, mainly as diverse agricultural utility items (Table 2). Most of the products were recorded sold for Rs.

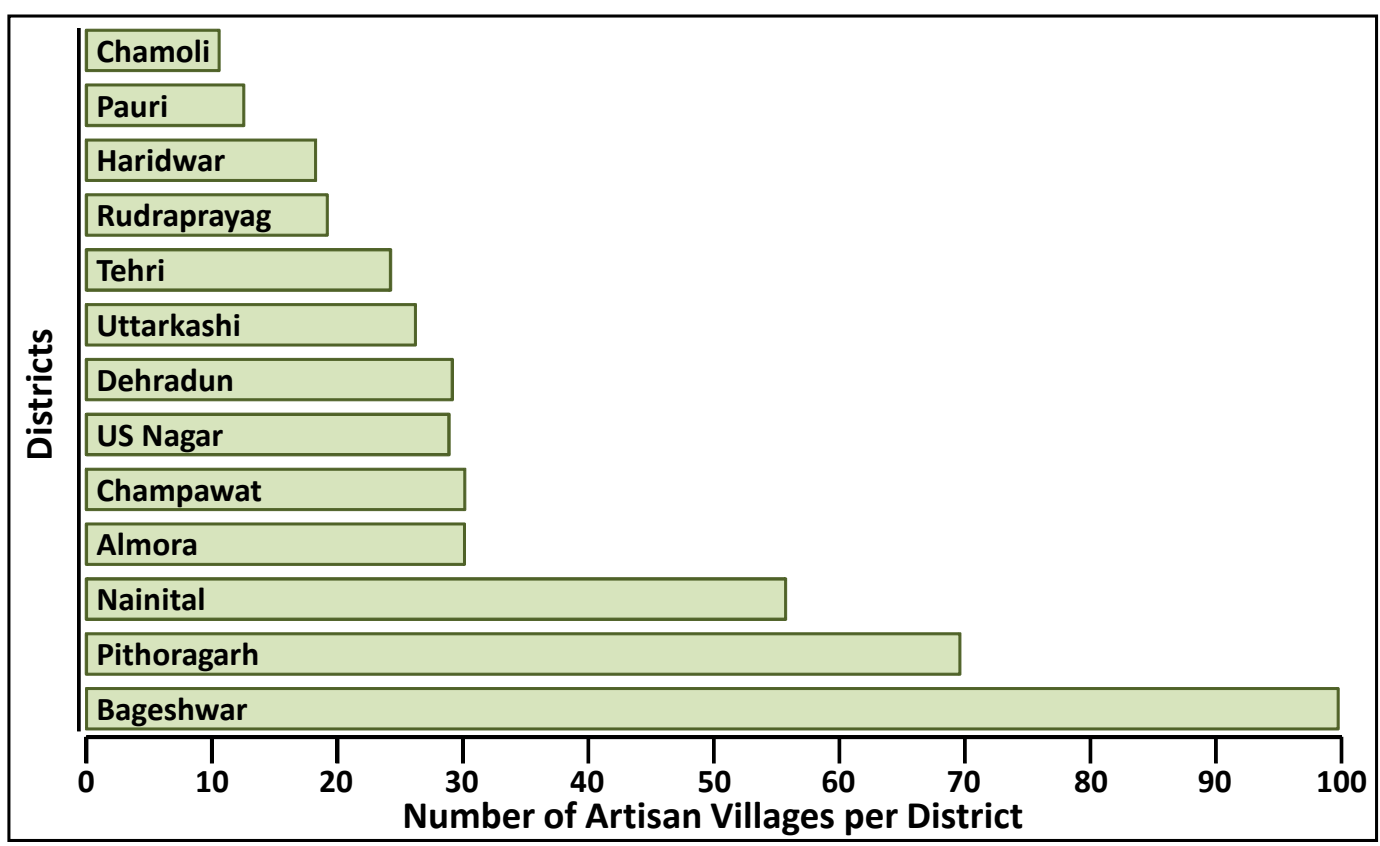

Figure 4. Distribution of artisan villages in districts of Uttarakand state, India. 


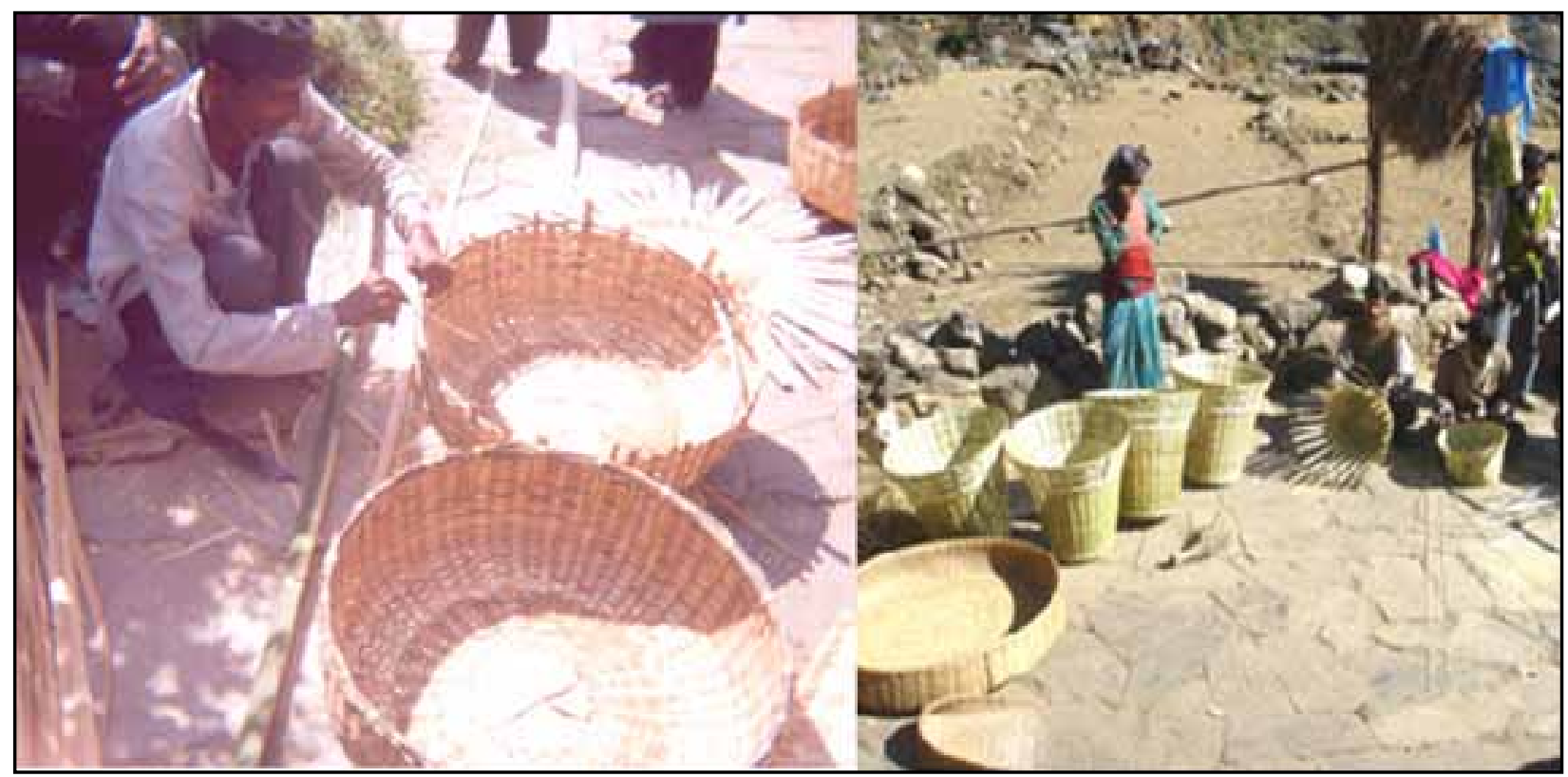

Figure 5. Traditional bamboo and ringal-bamboo items being made bby artisans in Uttarakhand, India.

Table 2. Important traditional bamboo products commonly used in Uttarakhand $(n=120)$

\begin{tabular}{|c|c|c|c|}
\hline Items & Local name & Bamboo spp. used & Locally use \\
\hline Big basket & Tokri (big) & $\begin{array}{l}\text { Dendrocalamus somdevae H.B. Naithani, } \\
\text { Himalayacalamus falconeri (Munro) Keng f. }\end{array}$ & $\begin{array}{l}\text { Fodder collection, carrying } \\
\text { manure }\end{array}$ \\
\hline Winnowing tray & Supa & $\begin{array}{l}\text { D. somdevae, Thamnocalamus spathiflorus } \\
\text { (Trin.) Munro, H. falconeri }\end{array}$ & Winnowing food grains \\
\hline Small basket & $\begin{array}{l}\text { Dalia } \\
\text { (small) }\end{array}$ & $\begin{array}{l}\text { D. somdevae, H. falconeri, T. spathiflorus, } \\
\text { Dendrocalamus strictus (Roxb.) Nees }\end{array}$ & $\begin{array}{l}\text { Children use for carrying } \\
\text { Chirpine leaves, } \\
\text { wood and manure }\end{array}$ \\
\hline $\begin{array}{l}\text { Big basket } \\
\text { with handle }\end{array}$ & Kandi (big) & $\begin{array}{l}\text { D. somdevae, Bambusa bambos (L.) Voss, } \\
\text { Himalayacalamus falconeri (Munro) Keng f., } \\
\text { T. spathiflorus }\end{array}$ & For storage of vegetables \\
\hline $\begin{array}{l}\text { Small basket } \\
\text { with handle }\end{array}$ & $\begin{array}{l}\text { Kandi } \\
\text { (small) }\end{array}$ & D. somdevae, T. spathiflorus & Used in marriage ceremony \\
\hline Round basket & Chapri & D. somdevae, H. falconeri, T. spathiflorus & $\begin{array}{l}\text { For keeping chapatti and } \\
\text { selling butter and cheese }\end{array}$ \\
\hline $\begin{array}{l}\text { Small round } \\
\text { basket }\end{array}$ & $\begin{array}{l}\text { Chapri } \\
\text { (small) }\end{array}$ & $\begin{array}{l}\text { D. somdevae, Dendrocalamus patellaris Gamble, } \\
\text { H. falconeri }\end{array}$ & $\begin{array}{l}\text { For sowing harela } \\
\text { (Hordeum sp.) }\end{array}$ \\
\hline $\begin{array}{l}\text { Food grain } \\
\text { storage basket }\end{array}$ & Topra & D. somdevae, D. patellaris, & For storage of food grains \\
\hline $\begin{array}{l}\text { Round sleeping } \\
\text { basket }\end{array}$ & $\begin{array}{l}\text { Choura } \\
\text { (Jhuger) }\end{array}$ & D. somdevae, $H$. falconeri & $\begin{array}{l}\text { For sleeping of newly born } \\
\text { baby }\end{array}$ \\
\hline Carrying basket & Doka & H. falconeri, T. spathiflorus & For carrying grass and fodder \\
\hline Carrying basket & Solta & H. falconeri & For carrying grass and fodder \\
\hline Mat & $\begin{array}{l}\text { Moste or } \\
\text { Bishal }\end{array}$ & T. spathiflorus, T. jaunsarensis & $\begin{array}{l}\text { For drying and } \\
\text { cleaning of rice }\end{array}$ \\
\hline Hat & Topi (cap) & T. falconeri & Cap \\
\hline Mouth trap & Mav & D. samdevii, T. falconeri & $\begin{array}{l}\text { Mouth traps for ploughing } \\
\text { animals (ox) }\end{array}$ \\
\hline
\end{tabular}


$10-45$ (1US\$= Rs. 45), which is a low and affordable price for the local communities. Only grain storage baskets are priced over Rs. 100 though their use has reduced to a large extent in recent times. It was estimated that the total selling price of items was $10-30 \%$ higher in the towns than in the villages. The artisans prefer to sell their items in the villages to avoid costs of transportation, time involved in selling, and labor from village to towns. It was also recorded that selling of the products in villages involved returns in cash and/or kind. In most cases manufacturing of the items was demand driven to meet the need of the villagers.

\section{Resource availability and consumption}

Most of the bamboo and ringal habitats fall under reserve forest, civil soyam (revenue forest) and van-panchayat (village forest) areas. Bamboo grows as an associate species in forest areas at low hills, which is collected by the Forest Corporation and auctioned through depots on regular intervals. This is similar to other cases for the Forest Divisions, thus showing the great challenge to manage the resource. The bamboo-artisans live at mid and high hill areas, and the demand for the bamboo is met from privately owned bamboo groves by villagers. Such groves comprising 3-5 clumps of bamboo are maintained in wastelands, gorges and stream banks. The cost of individual bamboo culms varied from Rs. 20-30 in different villages, and the mode of transportation is head load or back load. For ringal, the supply was met mainly from forest areas, viz. van-panchayat forests. At many places the villagers collect the ringal free of cost from van-panchayat areas for their domestic needs. However for additional requirement, a nominal fee was paid to the Forest Department. In areas where collection of ringal was banned, the raw material was collected illegally. The artisans spend 2 to 6 hours for collection of bamboo, while it takes between 6 hours to 2 days for collection of ringal.

An analysis of total annual village level consumption of bamboo articles revealed that nearly 600-3000 bamboo and ringal articles were used in different villages depending upon villages sizes. Utility of such a large number of bamboo articles/village proved that this trade was a major source of income for the artisans. The entire trade is labor intensive, from raw material procurement to processing and marketing. The bamboo from low hill forests under the control of the Forest Department was not accessible to artisans as such depots are in far-off areas from villages. Moreover, they sell bamboo in bulk, which is out of the capacity of the artisans. The artisans required low volume of raw material in the form of green bamboo throughout the year, which is purchased from selected farmers at high prices. The cost-benefit analysis of the trade showed that it was a low profile enterprise, therefore some families were diverting to other activities, such as seasonal labor in need of cash.

\section{Socio economic status of the artisans}

The socio-economic status of Barurees (bamboo-artisans) and Rudias (ringal artisans) in the state was very poor, which mainly comprised highly marginalized scheduled caste families. They lacked land and other productive resources for their livelihood and therefore have been dependent on bamboo trade for centuries. These communities sold bamboo articles to nearby villages to earn their livelihoods. A large number of such traders lived in remote villages; therefore most of them are not in a position to take the actual benefit of the government-run schemes. It was interesting to note that among all the studied villages the status of the bamboo-artisans (100\%) were recorded as below poverty line (BPL) scheduled caste (SC) families. In case of ringal, however, $75 \%$ of families were BPL (SC) while of the remaining only $15 \%$ of families were above the poverty line (APL) and the remaining $10 \%$ are below poverty line but not members of scheduled castes. All articles made by the artisans were used only for domestic purpose. The articles were sold directly to rural folk for cash or barter. Sometimes the items were sold in towns and festivals.

\section{Management of bamboo}

A major volume of the bamboo-trade in the state of Uttarakhand is concentrated in village areas and being run by highly marginalized communities that have low socioeconomic profile in the society. Despite their good skill for the processing of bamboo, these communities do not own the resources that they need. The bamboo-artisans purchase the raw material from private growers, while ringal artisans collect it directly from forests. Nearly $93 \%$ of ringal-artisans and $45 \%$ of bamboo-artisans directly collect the respective resources from forest areas. (The remaining $7 \%$ of ringal-artisans and $55 \%$ of bamboo-artisans purchase their materials.) There was no specific management done for maintaining and increasing area under bamboo by the owners. This is because bamboo is not a socially accepted species in Uttarakhand, therefore has not been adopted into plantations by the communities until recently. A greater awareness is desired for potential plantation growth of various bamboo species by local communities. Usually bamboo clumps were found in open areas and in wastelands. In those areas there was no protection from grazing animals which negatively disturbs the growth of new shoots. It is therefore important to extend the plantation technology of bamboo to the artisans.

The benefit of government run schemes yielded limited results because of various reasons including lack of organizing power, risk taking capacity, and awareness among the artisans. This study has found that $65 \%$ of artisan families earned an income that ranges from Rs. 2000 to Rs. 4000 per month, while the remaining $35 \%$ earned less than Rs. 2000 per month. In case of ringal, $20 \%$ of artisans earned between Rs. 4000 to Rs. $6000,55 \%$ earned 
between Rs. 2000 to Rs. 4000 and the remaining percent earned Rs. $<2000$. The data clearly depicted that the trade is highly subsistent as it requires high labor input, the products produced are in low volume, and there were low returns per family.

\section{Trade problem and future strategies}

The artisans also understand that the trade is highly subsistent but they do not have many options to replace it. When asked about how to change their status, the artisans expressed major concerns and priorities for development of bamboo based enterprises (Table 3). Scarcity of raw materials was cited as the most serious concern by the artisans. They feel that selection of new items and value addition to existing products could help to increase incomes and improve market demand. For this purpose, skill and capacity building was a key area to work on. Increasing access to credit and loans was also considered important to improve the status of artisans. The entrepreneurs also felt that the issues of resource conservation, involvement of the younger generation in bamboo trade, developing market linkages, lack of transportation, awareness on government policies and formation of artisans' cooperatives were important issues (Table 3). The concerns for resource ownership, availability of bamboo facility centers in nearby villages, high labor involvement in the

Table 3. Artisan perceptions of the bamboo trade in Uttarakhand state, India. Rank I, II and III represent very high, high and medium priority for any given preference by the community on bamboo and its trade. $(n=36)$

\begin{tabular}{|l|c|c|c|c|}
\hline \multirow{2}{*}{ Preferences } & \multicolumn{3}{|c|}{ Ranking } & \multirow{2}{*}{ Total } \\
\cline { 2 - 4 } & I & II & III & \\
\hline Scarcity of raw material & 6 & 5 & 4 & 15 \\
\hline Value addition to products & 5 & 4 & 5 & 14 \\
\hline $\begin{array}{l}\text { Skill development } \\
\text { activities }\end{array}$ & 6 & 4 & 2 & 12 \\
\hline Access to loans \& credits & 4 & 4 & 3 & 11 \\
\hline Conservation of resources & 5 & 2 & 3 & 10 \\
\hline $\begin{array}{l}\text { Lack of interest of } \\
\text { younger generation }\end{array}$ & 2 & 2 & 4 & 8 \\
\hline Market linkages \& access & 3 & 3 & 1 & 7 \\
\hline Lack of transportation & 1 & 3 & 1 & 5 \\
\hline $\begin{array}{l}\text { Awareness about } \\
\text { government policies }\end{array}$ & 1 & 2 & 2 & 5 \\
\hline Cooperative formations & 1 & 1 & 3 & 5 \\
\hline Resource ownership & 1 & 2 & 1 & 4 \\
\hline Bamboo facility centers & 0 & 2 & 2 & 4 \\
\hline Mainstreaming artisans & 0 & 1 & 2 & 3 \\
\hline High labor costs & 1 & 1 & 1 & 3 \\
\hline Advocacy for artisans & 0 & 0 & 2 & 2 \\
\hline
\end{tabular}

trade, and availability of advocacy services for artisans were other commonly cited priorities of the artisans. A critical analysis of artisans' concerns and priorities clearly depicts the major areas of interventions and policy formation for bamboo traders.

\section{Discussion}

Bamboo has provided a wide range of opportunities to rural communities all over; however until recently the socio-economic status of bamboo-artisans has been poor in view of low prices and quality of their material and products (Ghimire 2008, Nath \& Das 2008). In the past two decades greater attention has been given to building up income prospects of bamboo-artisans by improving quality of products and aiming for high-value marketplaces. For this purpose, there is a need to investigate bamboo-artisans' concerns that affect the resource status and trade. In this study we analyzed resource use patterns and business related issues being faced by bamboo-artisans in Uttarakhand state in North India. Uttarakhand state has significant areas under bamboo, and there are traditions of using this resource for various household utility items. The state government is strengthening infrastructure to widen this sector as an important vehicle for rural development (Anonymous 2005a). The use of bamboo is intense and comparable with the range of bamboo products made in various northeastern states (Singh et al. 2003, Sundriyal et al. 2002). However, in recent times only a few items were commonly sold in villages. Artisans use thick bamboo from community lands, while ringal-bamboo was collected from forest areas. The status of bamboo in both these areas has been limiting, therefore the cost of raw material has increased substantially over the years. All bamboo-artisan households were found to be below the poverty level, while two-third of ringal-bambooartisans were below the poverty level,. Those families in poverty lack land and other productive resources to support their livelihood, thus are dependent on subsistence bamboo trade (Anonymous 2005b). As the selling of the products in town markets involved intensive labor, cost of transportation, and time, artisans prefer to sell their products near raw material sources in rural areas to minimize transport costs and time. The cost-benefit analysis of the trade revealed that it was a low profit enterprise, which prompted many families to shift to seasonal labor. High labor requirement and the dwindling raw material status indicate high trade vulnerability (Ram \& Tandon 1997, Upreti \& Sundriyal 2001).

The study revealed a large number of challenges to develop the bamboo sector in the state of Uttarakhand. Resource ownership of artisans and management of existing bamboo stalks are key areas to begin with. This is unlike North East India where farmers manage their own bamboo gardens, thus maintaining enough resource under their control (Sarkar \& Sundriyal 2002). In Uttarakhand 
state the bamboo-artisans are facing problems of raw material availability in recent times. They lack bamboo plantation and propagation skills. The village communities do not promote bamboo plantation due to beliefs that traditionally bamboo is associated with the last rites of human beings. At low hill areas of the state, bamboo areas are still under the control of Forest Department. Such bamboo was auctioned in depots, thus rarely available to artisans (Anonymous 2005c). There is a challenge to conserve wild and farm grown bamboo stalks. Most products carry domestic use value only, which has a low profit earning opportunity. If this enterprise is to grow and thrive, there is a need to adopt a holistic approach so as to properly institutionalize resource conservation, supplementing artisans' needs, product development and marketing.

\section{Conclusions}

Proper use of bamboo resources applying modern technology can enhance the economy of bamboo-artisans as well as the state. There is tremendous potential for improving quality of bamboo products for meeting the demands of domestic and international markets. At global level, China has been leading the export market of bamboo products though India has the most area under bamboo (Lobovikov et al. 2007); therefore it has enough potential to compete in international markets. For this the traditional bamboo-artisans need to be targeted in all states in the country and their capacity needs to be built for making bamboo products of high market demand. This study reveals that in Uttarakhand state value addition of existing bamboo-products and skill development on such activities is highly warranted to earn higher incomes. For this purpose product diversification is a key area to work in to enhance quality of trade. Artisans' access to new tools for processing, technology for improving strength and durability of the products and use of improved finishing techniques are highly desirable, for which artisans' skill and capacity need to be built. Increasing artisans' access to loans/credit, markets and involvement of younger generations in the trade should receive high priority. Organizing artisans is another key to be addressed. Formation of artisans cooperatives is desired to promote advocacy for the artisans' cause and concerns. Furthermore, registration of artisans is necessary so that they get maximum benefit from government run schemes and other programs. The state government has set-up a few bamboo facility centers and it is suggested that their number is to be increased to cover all artisans. Moreover such centers should be linked with a series of programs to extend technical and financial training to artisans on a regular basis. Since most of the artisans are landless there is a need to give land to them so that they may plant bamboo and own the resource. There are government run schemes for the transfer of land to landless people and it is suggested that the bamboo-artisans are to be brought under such schemes. If some of these suggestions could be adopted and implemented, the bamboo-trade and artisans status could be improved substantially enhancing the economy of the state as well.

\section{Acknowledgements}

The authors thank Dr. L.M.S. Palni, Director, Govind Ballabh Pant Institute of Himalayan Environment \& Development, Kosi-Katarmal, Almora, Uttarakhand, India for providing facilities. The first author acknowledges financial support from the CSIR as Senior Research Associateship (Pool Scheme (Ref No.-13(8231-A)/pool/07) and DST, New Delhi as Women Scientist (WOS-B).

\section{Literature Cited}

Anonymous, 2002. Bamboo technology mission: The shoot of the matter is. Financial Daily May 31, 2002.

Anonymous. 2005a. Annual Report 2004-2005. Uttaranchal Bamboo \& Fiber Development Board. Government of Uttarakhand, Dehradun.

Anonymous. 2005b. National Mission on Bamboo Technology and Trade Development (NMBTTD). Department of Agriculture \& Cooperation, Ministry of Agriculture, Government of India, New Delhi, India.

Anonymous. 2005c. Uttaranachal Forest Development Corporation 2004-0: Annual Report. Government of Uttarakhand, Dehradun, India.

Anonymous. 2006. National Bamboo Mission: Operational guidelines. Department of Agriculture \& Cooperation, Ministry of Agriculture, Government of India, New Delhi, India.

Biswas, S. 2004. Bamboo diversity and conservation in India. www.ipgri.cgiar.org/publications/HTMLPublications/572/ch25.htm (5/12/2008).

Buckingham, K.C. 2009. Editor of Proceedings of the International CFC-ICB Workshop on Opportunities and Challenges of Certification for Commodities Harvested/ Extracted by the Rural Poor. International Network for Bamboo and Rattan (INBAR) \& Common Fund for Commodities (CFC). April 2, 2009, Beijing, China.

Frith, O. 2008. Editor of Mainstreaming Pro-poor Livelihood Opportunities with Bamboo. International Network for Bamboo and Rattan (INBAR), Beijing, China.

Ghimire, A. 2008. An Assessment of the Dependency of Farmers on Bamboo Resource for Rural Livelihood in Lalitpur District, Nepal. M.Sc. thesis. Institute of Organic Farming, Universität für Bodenkultur Wien, Austria. 
Kumar, B. 2009. Ringal (a dwarf bamboo): Resource use pattern. Reports and Opinion 1(4):1-5.

Lobovikov, M., S. Paudel, M. Piazza, H. Ren \& J. Wu. 2007. World bamboo resources: A thematic study prepared in the framework of the global forest resources assessment 2005. Non-Wood Forest Products 18, Food and Agriculture Organization, Rome, Italy.

Nath, A.J. \& A.K. Das. 2008. Bamboo resources in the homegardens of Assam: A case study from Barak valley. Journal of Tropical Agriculture 46(1-2):58-61.

Rai, S.N. \& K.V.S. Chauhan. 1998. Distribution and growing stock of bamboo in India. Indian Forester 124: 89-98.

Ram, H.Y.M. \& R. Tandon. 1997. Bamboo and rattans: From riches to rags. Proceedings of Indian National Science Academy 63: 245-267.

Sarkar, J. \& R.C. Sundriyal. 2002. Indigenous use, management and conservation of bamboo resource in Arunchal Pradesh, north east India. Bamboo Journal 19:24-39.
Sastry, C.B. 2001. Bamboo: Timber for 21st century. Draft paper for International Network for Bamboo and Rattan (INBAR), Beijing, China.

Saxena, N.C. 2004. Bamboo Workers and Forest Policy. http://planningcommission.nic.in/reports/articles/ncsxna/ bamboo.htm (25/3/2007).

Singh, H.B., B. Kumar \& R.S. Singh. 2003. Bamboo resources of Manipur: An overview for management and conservation. Journal of Bamboo and Rattan 2(1):43-55.

Sundriyal, R.C., T.C. Upreti \& R. Varuni. 2002. Bamboo and cane resource utilization and conservation in the Apatani plateau, Arunachal Pradesh, India: Implications for management. Journal of Bamboo and Rattan 1(3):205246.

Upreti, T.C. \& R.C. Sundriyal. 2001. Bamboo and cane resources of Arunachal Pradesh: Utilization pattern and implications for management. Bamboo Science and Culture 15(1):20-34. 